\title{
RESEARCH PAPER \\ Yield and chemical composition of massai grass fertilized with nitrogen
}

\section{Marcos N. Lopes ${ }^{1}$, Magno J. D. Cândido², Roberto C. F. F. Pompeu ${ }^{3}$, Rodrigo}

G. da Silva ${ }^{4}$, Claudivan Feitosa de Lacerda ${ }^{5}$, and Theyson Duarte Maranhão

${ }^{1}$ Federal Institute of Education, Science and Technology of Piauí (IFPI), Campus Valença of Piauí. Av. Joaquim Manoel, S/N, CEP 64300-000, Valença of Piauí, Piauí, Brazil

${ }^{2}$ Federal University of Ceará (UFC), Department Animal Science. Av. Mister Hull, s/nº, CEP 60970-355, Fortaleza, Ceará, Brazil

${ }^{3}$ Brazilian Agricultural Research Corporation (Embrapa) - Embrapa Goats and Sheep. Road Sobral/ Groaíras, CEP 62010-970, Sobral, Ceará, Brazil

${ }^{4}$ Federal Institute of Education, Science and Technology of Ceará (IFCE). Street Estevão Remígio, 1145, CEP 62930-000, Limoeiro do Norte, Ceará, Brazil

${ }^{5}$ Federal University of Ceará (UFC), Department Agricultural Engineering. Av. Mister Hull, $\mathrm{s} / \mathrm{n}^{\circ}, \mathrm{CEP}$ 60970-355, Fortaleza, Ceará, Brazil

${ }^{6}$ University of São Paulo, E.S.A. Luiz de Queiroz (USP-ESALQ). Av. Pádua Dias, CEP 13418-900, Piracicaba, São Paulo, Brazil

\begin{abstract}
M.N. Lopes, M.J.D. Cândido, R.C.F.F. Pompeu, R.G. da Silva, C.F. de Lacerda, and T.D. Maranhão. 2020. Yield and chemical composition of massai grass fertilized with nitrogen. Int. J.Agric. Nat. Resour. 69-78. Nitrogen fertilization, in addition to increasing biomass production, can also positively influence the chemical composition of a forage plant. The aim of this research was to evaluate the yield and chemical composition of Megathyrsus maximus cv. Massai grass under five nitrogen fertilization levels $\left(0,150,300,450\right.$ and $600 \mathrm{mg} \mathrm{N} \mathrm{dm}^{-3}$ soil, equivalent to $0,300,600,900$ and $1,200 \mathrm{~kg} \mathrm{ha}^{-1} \mathrm{year}^{-1}$, respectively) and during growth cycles (establishment and regrowth cycles) in a greenhouse. A completely randomized design with split-plot arrangement was adopted in which the five nitrogen levels were the plots and the cycles were the subplots. The total forage biomass increased with the nitrogen fertilization levels in the three growth cycles $\left(28.4 \mathrm{~g} \mathrm{pot}^{-1}, 32.0 \mathrm{~g} \mathrm{pot}^{-1}\right.$ and $29.8 \mathrm{~g} \mathrm{pot}^{-1}$ for establishment, regrowth 1 and regrowth 2, respectively, at the level of $600 \mathrm{mg} \mathrm{N}$ $\mathrm{dm}^{-3}$ ), and it was reduced from establishment to regrowth at lower $\mathrm{N}$ levels. The dry matter content was not affected by the $\mathrm{N}$ levels. However, this content presented higher values at the regrowth cycle in comparison to the establishment cycle. The crude protein $(\mathrm{CP})$ content increased (7.0\% $\mathrm{CP}$ at the level of $600 \mathrm{mg} \mathrm{N} \mathrm{dm}^{-3}$ ), while the neutral detergent fiber (NDF), acid detergent fiber (ADF) and hemicellulose (HEM) contents all decreased at higher $\mathrm{N}$ levels, with the highest CP content being observed at the establishment, and the opposite occurring for NDF, ADF and HEM. Nitrogen fertilization provides positive responses on yield and chemical composition of massai grass.
\end{abstract}

Keywords: Crude protein, forage biomass, Megathyrsus maximus, neutral detergent fiber, nitrogen fertilization.

\footnotetext{
Abbreviations used: N (nitrogen); TFB (total forage biomass); DM (dry matter); CP (crude protein); NDF (neutral detergent fiber); ADF (acid detergent fiber); HEM (hemicelluloses).
} 


\section{Introduction}

The need to intensify grazing production systems has increased the demand for studies on forage cultivars and their responses to intensive management. Massai grass (Megathyrsus maximus) has been shown to be promising and well adapted to intensive management because of its great capacity to emit leaves (Lopes et al., 2013a) and tillers (Lopes et al., 2016) and its quick regrowth after cutting or grazing (Lopes et al., 2011).

The production potential of a forage plant is determined genetically, but for this potential to be reached, abiotic conditions and management should be observed (Fagundes et al., 2005). The perennialism and productivity of forage plants demand adequate replacement of nutrients, which can be achieved through maintenance fertilization. Among the nutrients, nitrogen stands out in forage production (Fagundes et al., 2006) as it provides an increase in tillering (Alexandrino et al., 2004) and consequently in forage biomass production (Magalhães et al., 2006).

Nitrogen fertilization, besides enhancing the growth rate, also influences the chemical composition of forage plants (Benett et al., 2008; Mesquita \& Neres, 2008). The positive effect of nitrogen on the crude protein (CP) content of forage plants can be verified in the studies conducted by Andrade et al. (2003) and Rodrigues et al. (2005) in which the CP content of the forages increased with the increase of the nitrogen fertilization. Nitrogen fertilization may also lead to a decrease in the neutral detergent fiber (NDF) content (Vitor et al., 2009; Mota et al., 2010), although contradictory responses, such as positive responses of the NDF content to the nitrogen application, have also been verified in the literature (Rocha et al., 2002).

The chemical composition is one of the parameters used in the evaluation of the nutritive quality of forage plants. This approach shows the importance of knowing the chemical composition of forage plants in response to factors, such as environment and management, especially regarding nitrogen fertilization, as this nutrient has a great influence on the biomass production of forage plants. In this context, the objective of this research was to evaluate the yield and chemical composition of massai grass during the establishment and regrowth phases under different levels of nitrogen fertilization.

\section{Materials and Methods}

Description, treatments, and experimental design

This research was performed in a greenhouse at the Department of Plant Science of the Federal University of Ceará (UFC), in Fortaleza, Ceará (Brazil). Fortaleza represents climate type Aw', rainy, tropical, according to the Köppen climate classification (Köppen, 1948). Minimum and maximum temperatures were recorded daily (inside the greenhouse), with mean values of 25.8 and $40.5{ }^{\circ} \mathrm{C}$ (establishment), 25.6 and 40.6 ${ }^{\circ} \mathrm{C}$ (regrowth 1), and 25.9 and $40.9^{\circ} \mathrm{C}$ (regrowth 2), respectively.

The forage plant used was Megathyrsus maximus cv. Massai (massai grass). Five nitrogen levels were assessed (0, 150, 300, 450 and $600 \mathrm{mg} \mathrm{N}$ $\mathrm{dm}^{-3}$ soil), which are equivalent to $0,300,600$, 900 and $1,200 \mathrm{~kg} \mathrm{ha}^{-1}$ year $^{-1}$, respectively, and growth cycles (establishment, regrowth 1 and regrowth 2) were used for the evaluation of total forage biomass, establishment and regrowth, and for chemical composition, considering the average of the regrowth cycles. The treatments (nitrogen levels $\mathrm{x}$ growth cycles) were evaluated following the principles of a completely randomized design in split plot in time, with five replications, considering the five nitrogen levels as plots and the growth cycles (establishment, regrowth 1 and regrowth 2) as subplots.

The soil used in the experiment was Yellow Argisol. After collected, the soil was sieved for better 
homogenization and retention of coarse materials. Soil samples from the $0-20 \mathrm{~cm}$-deep layer presented the following chemical composition: 4 $\mathrm{mg} \mathrm{dm}{ }^{-3}$ of P; $76 \mathrm{mg} \mathrm{dm}^{-3}$ of K; $2.0 \mathrm{cmol}_{\mathrm{c}} \mathrm{dm}^{-3}$ of $\mathrm{Ca}^{2+} ; 1.9 \mathrm{cmol}_{\mathrm{c}} \mathrm{dm}^{-3}$ of $\mathrm{Mg}^{2+} ; 0.0 \mathrm{cmol}_{\mathrm{c}} \mathrm{dm}^{-3}$ of $\mathrm{Al}^{3+}$; $11 \mathrm{mg} \mathrm{dm}^{-3}$ of $\mathrm{Na}^{+}$; $9.10 \mathrm{~g} \mathrm{~kg}^{-1}$ of organic matter; sum of bases $(\mathrm{SB})=4.14 \mathrm{cmol}_{\mathrm{c}} \mathrm{dm}^{-3}$; total cation exchange capacity $(\mathrm{tCEC})=4.14 \mathrm{cmol}_{\mathrm{c}} \mathrm{dm}^{-3} ; \mathrm{pH}$ in water $5.7 ; 19.0 \mathrm{mg} \mathrm{dm}^{-3}$ of $\mathrm{Fe}^{2+} ; 0.14 \mathrm{mg} \mathrm{dm}^{-3}$ of $\mathrm{Cu}^{2+} ; 3.91 \mathrm{mg} \mathrm{dm}^{-3}$ of $\mathrm{Zn}^{2+}$ and $12.18 \mathrm{mg} \mathrm{dm}^{-3}$ of $\mathrm{Mn}$. For the fertilization, the recommendation of Ribeiro et al. (1999) was followed for fertility levels suggested for grasses with high yield potential and high technological level.

The pots were randomly distributed inside the greenhouse. When filling the pots, which had a capacity of $10 \mathrm{dm}^{3}$ each, the soil correction was performed with the application of $6.169 \mathrm{~g} \mathrm{pot}^{-1}$ of limestone, according to the fertility analysis, aiming to increase calcium content and $\mathrm{pH}$ value. The samples received daily irrigation for ten days to speed up the limestone reaction.

The control of the daily irrigation to be applied was done by installing mercury tensiometers $(\mathrm{Hg})$ in the pots (two tensiometers per treatment), with water replacement when the mercury column (h) reached approximately $10 \mathrm{~cm}$ (approximate $\left.\psi_{\mathrm{m}}-7.98 \mathrm{kPa}\right)$ in the treatments supplied with higher levels of nitrogen (600 $\mathrm{mg} \mathrm{N} \mathrm{dm}^{-3}$ soil). The treatment that received the $600 \mathrm{mg} \mathrm{N} \mathrm{dm}^{-3}$ of soil was the reference for the water replacement applied in the other treatments, according to the equation $\psi_{\mathrm{m}}=-12.6 \mathrm{~h}+\mathrm{h}_{1}+\mathrm{z}$, where $\psi_{\mathrm{m}}=$ matric potential in $\mathrm{cm}$ of water column; $\mathrm{h}=$ height of mercury column $(\mathrm{Hg})$ in the gauge in $\mathrm{cm} ; \mathrm{h}_{1}$ $=$ height of the $\mathrm{Hg}$ level in the gauge in $\mathrm{cm}$, in relation to the soil surface, and $\mathrm{z}=$ depth of the porous cup in $\mathrm{cm}(10 \mathrm{~cm})$ (Amaro Filho et al., 2008). At the end of the irrigation, the $\mathrm{Hg}$ column height in the gauge $(\mathrm{cm})$ was registered, which presented approximately $5.0 \mathrm{~cm}$ (approximate $\left.\psi_{\mathrm{m}}-1.80 \mathrm{kPa}\right)$ for all treatments. Thus, the soil moisture conditions were kept near field capacity in all experimental units.
Sowing was performed using an average of 50 seeds per pot. Prethinning was done eight days after emergence maintaining 12 plants per pot, which were reduced to three after the final thinning, 13 days after emergence.

Three cuts were performed; the first cut was carried out for uniformity (at the end of the establishment cycle), which used the horizontal length of the pseudo stem as a reference. Based on that, all plants in the pot were cut, with only a residue of $10 \mathrm{~cm}$ of stem length remaining, 43 days after seedling emergence. This criterion was adopted with the aim to standardize the cut plants, since they presented growth with different inclination angles of the tiller, impairing the cutting uniformity in case the cut was done at a fixed vertical height. The second and third cuts (at the end of the regrowth 1 and regrowth 2 cycles, respectively) followed the same criterion and were performed after a rest period of 28 days.

Fertilizations of phosphate (simple superphosphate), potassium (potassium chloride) and micronutrients (FTE BR-12, with 0.1\% Mo, $0.8 \% \mathrm{Cu}, 1.8 \% \mathrm{~B}, 2.0 \% \mathrm{Mn}, 3.0 \% \mathrm{Fe}$, and $9.0 \%$ $\mathrm{Zn}$ ) were performed according to the results of the soil analysis as well as the application of limestone. The applications of nitrogen (urea) and potassium were split. At the establishment cut, the nitrogen dose for each treatment was divided into two; the first half was applied soon after final thinning, and the second half was applied after 14 days. In all nitrogen applications, the urea was diluted in the irrigation water for a more uniform fertilizer application. The nitrogen levels assessed $(0,150,300,450$ and $600 \mathrm{mg} \mathrm{N}$ $\mathrm{dm}^{-3}$ soil) were calculated for pots that had the capacity of $10 \mathrm{dm}^{3}$ each.

The potassium was supplied in two applications; the first $\left(120 \mathrm{mg} \mathrm{dm}^{-3}\right.$ of $\left.\mathrm{K}_{2} \mathrm{O}\right)$ was applied at the moment of sowing, and the second $\left(120 \mathrm{mg} \mathrm{dm}^{-3}\right.$ of $\mathrm{K}_{2} \mathrm{O}$ ) was applied via water solution, which was performed soon after the uniformity cut along with the first nitrogen dose at regrowth 1 . Phosphorus 
supply ( $125 \mathrm{mg} \mathrm{dm}^{-3}$ of $\mathrm{P}_{2} \mathrm{O}_{5}$ ) was performed once at the time of sowing. At that moment, micronutrients ( $25 \mathrm{mg} \mathrm{dm}^{-3}$ of FTE BR-12) were also provided. The second half of the nitrogen level for each treatment applied at regrowth 1 was applied in the middle of the rest period (28-day cycles). At regrowth 2, the same management was followed.

\section{Response variables}

At the end of each cycle, following the rest period adopted for the forage plant, all plants of each experimental unit were harvested and taken to the laboratory. The samples were placed in a forced ventilation oven $\left(55^{\circ} \mathrm{C}\right.$ until reaching constant weight) for later calculation of the total forage biomass yield (TFB) in a dry matter (DM) basis (g DM pot $\left.{ }^{1}\right)$.

For the chemical determinations, the growth of establishment and the average of the two regrowth cycles (representing the growth in regrowth 1 and 2 , since it was not possible to evaluate the regrowth 1 and 2, separately, due to the little amount of dry biomass of the treatment control) were evaluated. After predrying, the contents of DM (\%, method ID 930.15), crude protein (CP, $\%$ in the DM, method ID 984.13) (Helrich, 1990), neutral detergent fiber (NDF, \% in the DM), acid detergent fiber (ADF, \% in the DM) and hemicellulose (HEM, \% in the DM) were analyzed (Van Soest \& Robertson, 1985; Van Soest et al., 1991).

\section{Data analysis}

The statistical model used in the experiment was as follows:

$\mathrm{y}_{\mathrm{ijk}}=\mu+\alpha_{\mathrm{i}}+\varepsilon_{(\mathrm{ijj}}+\tau_{\mathrm{j}}+(\alpha \tau)_{\mathrm{ij}}+\varepsilon_{\mathrm{ijk}}$,

where $\mathrm{y}_{\mathrm{ijk}}=$ the value observed in the experimental plot that received level $i$ of factor $\alpha$ (nitrogen fertilization) and level $j$ of factor $\tau$ (growth cycles) in replication $k$; $\mu=$ the general constant;

$\alpha_{\mathrm{i}}=$ the effect of level $i$ of factor $\alpha(i=1,2,3$, 4, and 5);

$\varepsilon_{(\mathrm{i}) \mathrm{j}}=$ the effect of level $i$ of factor $\alpha$ in replication $k$ (error a);

$\tau_{\mathrm{j}}=$ the effect of level $j$ of factor $\tau(j=1,2$, and 3 for the evaluation of total forage biomass and $j$ $=1$ and 2 for chemical composition);

$(\alpha \tau)_{\mathrm{ij}}=$ the effect of the interaction between level $i$ of factor $\alpha$ and level $j$ of factor $\tau$; and

$\varepsilon_{\mathrm{ijk}}=$ the experimental error (error b).

The data were subjected to analysis of variance, means comparison test and regression analysis.

The interaction of fertilization levels and growth cycles was analyzed when significant at $\mathrm{P}<0.05$ through the $\mathrm{F}$ test. The effect of the nitrogen fertilization levels was assessed by regression analysis. The growth cycles were compared by Tukey's test. The models were chosen based on the significance of the linear and quadratic coefficients through Student's t-test $(\mathrm{P}<0.05)$ and on the coefficient of determination. SAS (Statistical Analysis System, version 9.0, SAS Institute, Inc., Cary, NC) procedures MIXED and GLM were employed.

\section{Results}

\section{Total forage biomass}

An interaction effect $(\mathrm{P}<0.05)$ between nitrogen levels and growth cycles was observed on TFB, which increased $(\mathrm{P}<0.01)$ as the nitrogen levels increased in the three growth cycles (Figure 1) but decreased $(\mathrm{P}<0.05)$ from the establishment to the regrowth cycles in the absence and at lower levels of nitrogen (Figure 1). The interaction effect reflects the increase of TFB that is due to the $\mathrm{N}$ levels being more pronounced in regrowth 
2 in comparison to the increments observed in the regrowth 1 cycles and establishment (Figure 1). The total forage biomass ranged from 16.7 to $28.4 \mathrm{~g} \mathrm{pot}^{-1}$ (establishment), from 9.4 to 32.0 $\mathrm{g} \mathrm{pot}^{-1}$ (regrowth 1) and from 3.5 to $29.8 \mathrm{~g} \mathrm{pot}^{-1}$ (regrowth 2) for the levels 0 to $600 \mathrm{mg} \mathrm{N} \mathrm{dm}^{-3}$. Increases of $71 \%$ (establishment), $240 \%$ (regrowth 1) and $751 \%$ (regrowth 2 ) were observed at the level $600 \mathrm{mg} \mathrm{N} \mathrm{dm}^{-3}$ in comparison to the absence of nitrogen fertilization.

\section{Chemical composition}

For DM content, no effect of the interaction between growth cycles and nitrogen levels was observed $(\mathrm{P}>0.05)$. An increase $(\mathrm{P}<0.05)$ in $\mathrm{DM}$ content was observed when comparing the establishment $(29.3 \%)$ to the average of the two regrowth cycles (32.3\%) (Figure 2), and the DM content was not affected $(\mathrm{P}>0.05)$ by the nitrogen fertilization.

The CP and NDF contents were not affected $(\mathrm{P}>0.05)$ by the interaction between nitrogen levels and growth cycles, with significance $(\mathrm{P}<0.05)$ being limited to the main factors. A positive linear response $(\mathrm{P}<0.01)$ was observed for the $\mathrm{CP}$ content

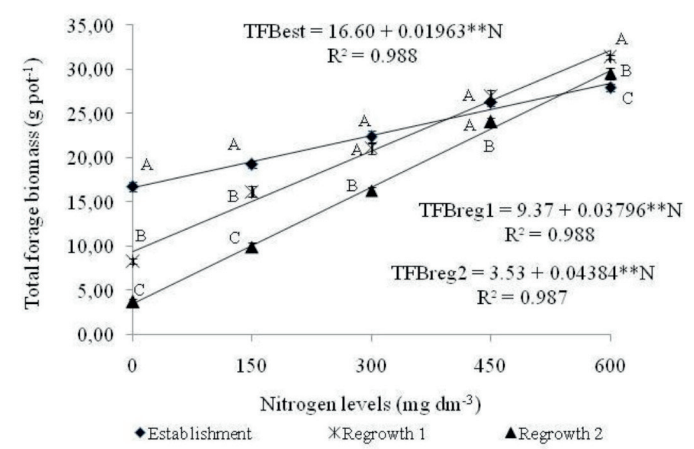

Figure 1. Total forage biomass (TFB) in massai grass according to nitrogen levels during three growth cycles (establishment, regrowth 1 and regrowth 2).

** Significant at $1 \%$.

Means followed by different letters on the same nitrogen level are significantly different $(\mathrm{P}<0.05)$ by Tukey's test. The bars represent the standard error of the mean.
(Figure 3A), while for the NDF content, a linear decrease was observed $(\mathrm{P}<0.01)$ as the nitrogen levels increased (Figure 3B). Estimated values of 6.0 to $7.0 \%$ for $\mathrm{CP}$ and 77.4 to $70.3 \%$ for NDF were observed for the levels of 0 and $600 \mathrm{mg} \mathrm{N}$ $\mathrm{dm}^{-3}$, respectively, corresponding to an increase of $17.4 \%$ in the CP content and a reduction of $10.1 \%$ in the NDF content, at the level $600 \mathrm{mg}$ $\mathrm{N} \mathrm{dm}^{-3}$ in comparison to the control treatment (absence of $\mathrm{N}$ ). The $\mathrm{CP}$ content reduced $(\mathrm{P}<0.05)$ when comparing the establishment $(7.1 \% \mathrm{CP})$ to the mean of the two regrowth cycles $(5.9 \% \mathrm{CP})$ while the NDF responded inversely and was higher $(\mathrm{P}<0.05)$ in the regrowth cycles (Figure 2$)$.

For ADF and HEM contents, no interaction was observed between growth cycles and nitrogen levels $(\mathrm{P}>0.05)$, but both variables increased $(\mathrm{P}<0.05)$ from the establishment (31.9\% of ADF and 32.9\% of HEM) to the average of the two regrowth cycles (34.0\% of ADF and $37.0 \%$ of HEM) (Figure 2 ). For the contents of ADF (Figure 4A) and HEM (Figure $4 \mathrm{~B})$, a decreasing linear response $(\mathrm{P}<0.01)$ was observed with the increase in the nitrogen levels, revealing estimated values of 33.9 and $32.0 \%$ of ADF and 36.9 and $32.9 \%$ of HEM for 0 and 600 $\mathrm{mg}$ of $\mathrm{N} \mathrm{dm}^{-3}$ of soil, respectively.

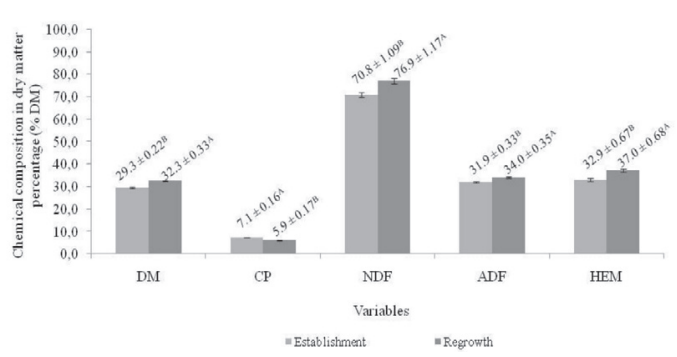

Figure 2. Dry matter (DM), crude protein (CP), neutral detergent fiber (NDF), acid detergent fiber (ADF) and hemicellulose (HEM) in massai grass according to growth cycles (establishment and regrowth) in average nitrogen levels.

Means followed by different letters on the same variable are significantly different $(\mathrm{P}<0.05)$. The bars represent the standard error of the mean. 


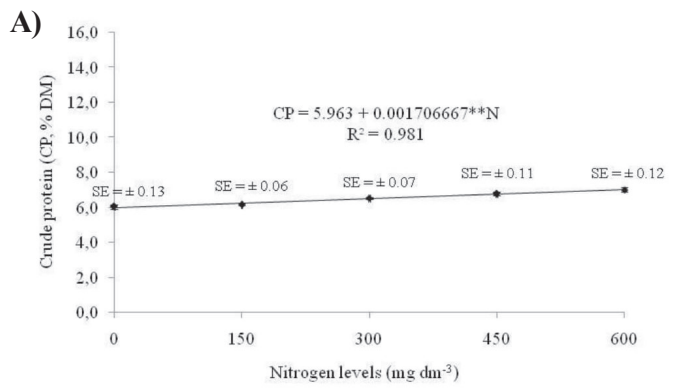

B)

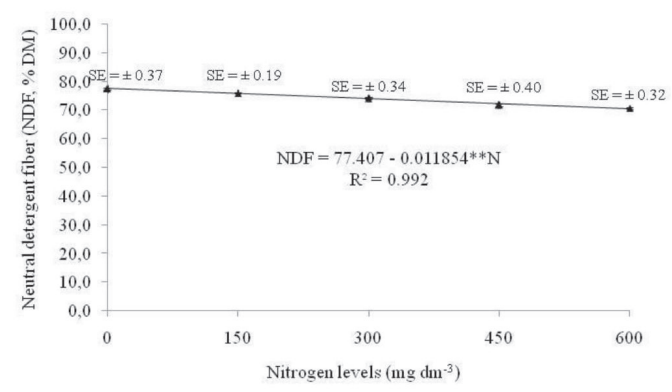

Figure 3. Crude protein (A) and neutral detergent fiber (B) in massai grass according to nitrogen levels in average growth cycles.

**Significant at $1 \%$. The bars represent the standard error (SE) of the mean.

\section{Discussion}

\section{Total forage biomass}

The plants that had higher nitrogen input presented higher TFB production (Figure 1), thus proving the beneficial effect of the nitrogen fertilization in intensively managed pastures (Fagundes et al., 2006). The influence of nitrogen on TFB in massai grass can be attributed to the increase in the leaf appearance rate (Martuscello et al., 2005) and the effect of nitrogen on the leaf elongation rate (Martuscello et al., 2006; Lopes et al., 2013), which can be especially attributed to the increase in cell production (Volenec \& Nelson, 1984) and to the influence of nitrogen on physiological processes of the plant (Fagundes et al., 2005), which contributes to the growth and development of the forage plant. It is also worth mentioning the positive effect of nitrogen on the tiller population

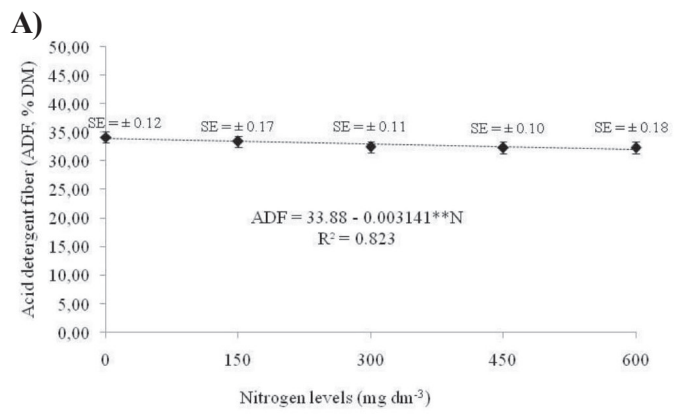

B)

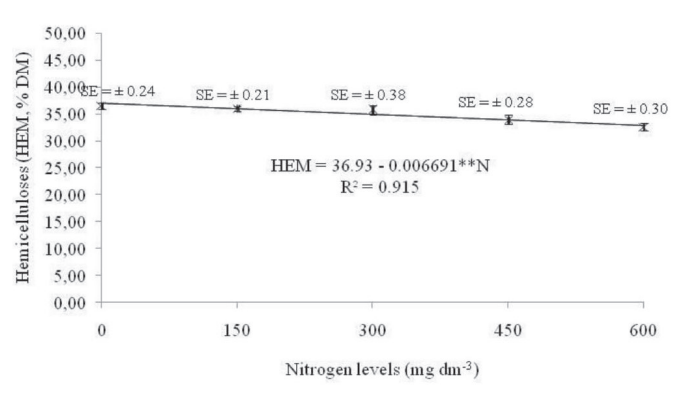

Figure 4. Acid detergent fiber (A) and hemicelluloses (B) in massai grass according to nitrogen levels in average growth cycles.

**Significant at $1 \%$. The bars represent the standard error (SE) of the mean.

density (TPD), which contributes to the increase in total forage biomass of massai grass (Lopes et al., 2011). With successive cuts, a more pronounced reduction in TFB at lower levels was observed, which denotes greater nitrogen depletion and is due to the lower dose applied (Figure 1).

\section{Chemical composition}

The DM content was not influenced by the nitrogen fertilization, and this may be a relevant indicator of the adequate adjustment of the irrigation management in which the water demand of the different treatments under nitrogen levels was treated differently according to the daily quantity of water for each level of nitrogen. Thus, treatments of higher nitrogen levels presented higher water demand and were supplied with larger daily water amounts. Such management in the water 
supply possibly provided equilibrium on water balance in the plant for the different nitrogen levels, thus neutralizing some indirect effect of the nitrogen levels on the dry matter content of massai grass. An increase in the DM content was observed when comparing the establishment to the average of the two regrowth cycles (Figure 2 ), reflecting the slower growth of the grass at the establishment, resulting in lower physiological age, despite the higher chronological age (43 vs. 28 days).

The increase in $\mathrm{CP}$ content with increasing nitrogen levels (Figure 3A) occurred due to the relevant role of this nutrient. After absorption, nitrogen is reduced to the ammoniacal form, and when it is combined in the organic chains, it forms glutamic acid, which is a precursor of different amino acids, from which approximately 20 are used in protein formation (Raij, 1991). Thus, the increase observed for $\mathrm{CP}$ content reflects the greater presence of free amino acids, which maintain the nitrogen in its structure, and in the form of small peptides in the plant tissue, in response to the higher nitrogen input in the soil (Freitas et al., 2007). Despite the increase in the CP content, it is worth noting that only at the highest level $\left(600 \mathrm{mg} \mathrm{N} \mathrm{dm}^{-3}\right)$ did this variable reach the critical value (7.0\%) proposed by Van Soest (1965). According to this author, with CP contents lower than $7.0 \%$, a reduction in intake and digestion of forage occurs because of inadequate levels of nitrogen for rumen microorganisms. To meet the protein requirements of ruminant animals, it is necessary to formulate a diet with $\mathrm{CP}$ content higher than $7.0 \%$ as reported by Benett et al. (2008). In this study, the conditions of elevated temperature (greenhouse), the fixed rest period for all nitrogen levels and probably the effect of dilution of nitrogen on forage biomass, contributed to the small increments on CP content, even at high levels of nitrogen. Therefore, in order to overcome a low $\mathrm{CP}$ content in a pasture, managers should design management strategies based on the morphophysiological characteristics of massai grass. This includes, for example, defin- ing the moment of defoliation based on variables related to the physiology of the pasture, such as interception of photosynthetically active radiation, number of leaves per tiller, and beginning of leaf senescence, to balance quantity and quality without compromising the perennialism and productivity of the pasture.

The reduction observed for the NDF content (Figure $3 \mathrm{~B}$ ) probably occurred because of the nitrogen stimulating effect, causing the rise of new axillary tillers, which present smaller leaves that also have a smaller midrib (Andrade et al., 2003), resulting in lower proportion of fibrous tissue. The response pattern observed for the NDF content in the present study shows the beneficial effect of nitrogen fertilization on this variable, corroborating the results found by Vitor et al. (2009) and Mota et al. (2010). These authors observed a decrease in NDF content along with nitrogen fertilization, which may be related to the fact that nitrogen stimulates the growth of new plant tissues that have lower contents of structural carbohydrates, leading to a reduction in the percentage of NDF.

The response observed for both variables (higher CP content and lower NDF content in the establishment) (Figure 2) occurred because of the higher proportion of young tillers in the establishment, resulting in a higher proportion of biomass components with physiologically younger tissues in the establishment cycle, as verified during the biomass flow assessments (Lopes et al., 2013b). With the greater presence of physiologically younger tissues, the participation of cellular content is higher, in detriment to the constituents of the cell wall, explaining the 1.2 and 6.1 percentage points of difference for the $\mathrm{CP}$ and NDF contents, respectively, from the establishment to the regrowth.

The effect of nitrogen in both constituents of the cell wall (ADF and HEM) possibly reflects the favoring of the morphogenic process, with the more intense flow in massai grass (Lopes et 
al., 2013b) causing a higher production and an increase in the proportion of new tissues, with lower ADF and HEM contents followed by an increase in CP content that is due to nitrogen, which characterizes a pasture with better nutritive value. The $\mathrm{ADF}$ content at all nitrogen levels remained below the critical value of $40 \%$ (Nussio et al., 1998). According to these authors, forages with levels of ADF greater or equal to $40 \%$, present lower digestibility.

The observed response for the ADF content (increasing from the establishment to the average of the regrowth cycles) occurred because of the faster growth of the grass during regrowth, leading to a higher physiological age, despite the lower chronological age, as previously mentioned. The superior hemicellulose content in the average of the regrowth cycles is explained by the effect of the growth cycle factor on the NDF and ADF variables, which increased from the establishment to the regrowth, since the variable in consideration (HEM) is the result of the difference between the concentrations of NDF and ADF (HEM = $\mathrm{NDF}-\mathrm{ADF}$ ).

Nitrogen fertilization promotes positive responses on forage biomass production and the chemical composition of massai grass up to the nitrogen level of $600 \mathrm{mg} \mathrm{dm}^{-3}$ of soil. The forage biomass yield and the chemical composition of massai grass are modified by the growth cycles, with more pronounced differences in productivity found between cycles at the lowest nitrogen levels and with better quality forage biomass found in the establishment growth.

\section{Resumen}

M.N. Lopes, M.J.D. Cândido, R.C.F.F. Pompeu, R.G. da Silva, C.F. de Lacerda, and T.D. Maranhão. 2020. Productividad y composición química del pasto massai fertilizado con nitrógeno. Int. J.Agric. Nat. Resour. 69-78. La fertilización nitrogenada, además de incrementar la producción de biomasa, también puede influenciar positivamente en la composición química de la planta forrajera. El objetivo de este estudio fue evaluar la productividad y la composición química del Megathyrsus maximus cv. Massai durante el establecimiento y rebrote en invernadero bajo cinco dosis de nitrógeno $\left(0,150,300,450\right.$ y $600 \mathrm{mg} \mathrm{N} \mathrm{dm}^{-3}$ de suelo). Se adoptó un diseño completamente aleatorio, en arreglo de parcelas subdivididas, siendo las dosis de nitrógeno asignadas en las parcelas y los ciclos, en las subparcelas. La biomasa de forraje total fue incrementada con las dosis de nitrógeno en los tres ciclos de crecimiento $(28,4 \mathrm{~g}$ vaso${ }^{1}, 32,0 \mathrm{~g} \mathrm{vaso}^{-1}$ y $29,8 \mathrm{~g} \mathrm{vaso}^{-1}$ para el establecimiento, rebrote 1 y rebrote 2 , respectivamente, en la dosis de $600 \mathrm{mg} \mathrm{N} \mathrm{dm}^{-3}$ ) y fue reducida de forma más expresiva del establecimiento para los rebrotes en las menores dosis de N. El contenido de materia seca no fue influenciado por las dosis de $\mathrm{N}$, sin embargo, reveló mayor valor en el rebrote con relación al establecimiento. El contenido de proteína bruta (PB) fue incrementado (7,0\% en la dosis de $600 \mathrm{mg} \mathrm{N} \mathrm{dm}^{-3}$ de suelo) y los contenidos de fibra en detergente neutro (FDN), de fibra en detergente ácido (FDA) y de hemicelulosa (HEM) fueron reducidos en las mayores dosis de $\mathrm{N}$, con el contenido de PB siendo superior en el establecimiento y el inverso ocurriendo para los contenidos de FDN, FDA y HEM. La fertilización nitrogenada proporciona respuestas positivas en la productividad y composición química del pasto-massai.

Palabras clave: Biomasa de forraje, fertilización nitrogenada, fibra en detergente neutro, proteína bruta, Megathyrsus maximus. 


\section{References}

Alexandrino, E., Nascimento Júnior, D., Mosquim, P. R., Regazzi, A. J., \& Rocha, F. C. (2004). Características morfogênicas e estruturais na rebrotação da Brachiaria brizantha cv. Marandu submetida a três níveis de nitrogênio. Revista Brasileira de Zootecnia, 33(6):1372-1379. 10.1590/S151635982004000600003

Amaro Filho, J., Assis Júnior, R. N., \& Mota, J. C. A. (2008). Física do solo: conceitos e aplicações. Fortaleza: Editora Imprensa Universitária. $290 \mathrm{p}$.

Andrade, A. C., Fonseca, D. M. da Queiroz, D. S., Salgado, L. T., \& Cecon, P. R. (2003). Adubação nitrogenada e potássica em capim-elefante (Pennisetum purpureum Schum. cv. Napier). Ciência e Agrotecnologia, Ed. Esp:1643-1651.

Benett, C. G. S., Buzetti, S., Silva, K. S., Bergamaschine, A.F., \& Fabricio, J. A. (2008). Produtividade e composição bromatológica do capim-marandu a fontes e níveis de nitrogênio. Ciência e Agrotecnologia, 32(5):1629-1636. 10.1590/ S1413-70542008000500041

Fagundes, L.J., Fonseca, D. M., Gomide, J. A., Nascimento Júnior, D. do., Vitor, C. M. T., Morais, R. V. de., Mistura, C., Reis, G. da C., \& Martuscello, J. A. (2005). Acúmulo de forragem em pastos de Brachiaria decumbens adubadas com nitrogênio. Pesquisa Agropecuária Brasileira, 40(4):397403. 10.1590/S0100-204X2005000400012

Fagundes, J. L., Fonseca, D. M. da., Morais, R. V. de., Mistura, C., Vitor, C. M. T., Gomide, J. A., Nascimento Júnior, D. do., Santos, M. E. R., \& Lambertucci, D. M. (2006). Avaliação das características estruturais do capim-braquiária em pastagens adubadas com nitrogênio nas quatro estações do ano. Revista Brasileira de Zootecnia, 35(1):30-37. 10.1590/S151635982006000100004

Freitas, K. R., Rosa, B., Ruggiero, J. A., Nascimento, J. L., Heinemam, A. B., Macedo, R. F., Naves, M. A. T., \& Oliveira, I. P. de. (2007). Avaliação da composição químico-bromatológica do capim mombaça (Panicum maximum Jacq.) submeti- do a diferentes níveis de nitrogênio. Bioscience Journal, 23(3):1-10.

Helrich, K. (Ed.) (1990). Official methods of analysis of the AOAC. 15th ed. Arlington: Association of Official Analytical Chemists. 1117 p.

Lopes, M. N., Cândido, M. J. D., Pompeu, R. C. F. F., Silva, R. G. da., Lopes, J. W. B., \& Bezerra, F. M. L. (2011). Biomass components in massai grass during establishment and regrowth under five nitrogen fertilization levels. Revista Brasileira de Zootecnia, 40(8):1629-1637. 10.1590/ S1516-35982011000800002

Lopes, M. N., Cândido, M. J. D., Pompeu, R. C. F. F., Silva, R. G. da., Carvalho, T. C. F. de., Sombra, W. A., Morais Neto, L.B. de., \& Peixoto, M. J. A. (2013a). Biomass flow in massai grass fertilized with nitrogen under intermittent stocking grazing with sheep. Revista Brasileira de Zootecnia, 42(1):13-21. 10.1590/S151635982013000100003

Lopes, M.N., Cândido, M. J. D., Pompeu, R. C. F. F., Silva, R. G. da., Lopes, J. W. B., F Fernandes, R. B., Lacerda, C. F., \& Bezerra, F. M. L. (2013b). Fluxo de biomassa em capim-massai durante o estabelecimento e rebrotação com e sem adubação nitrogenada. Revista Ceres, 60(3):363-371.

Lopes, M. N., Cândido, M. J. D., Pompeu, R. C. F. F., Silva, R. G. da., Morais Neto, L. B. de., \& Carneiro, M. S. S. (2016). Tillering dynamics in massai grass fertilized with nitrogen and grazed by sheep. Bioscience Journal, 32(2):446-454. 10.14393/BJ-v32n2a2016-26106

Magalhães, J. A., Lopes, E. A., Rodrigues, B. H. N., Costa, N. de L., Barros, N. N., \& Mattei, D. A. (2006). Influência da adubação nitrogenada e da idade de corte sobre o rendimento forrageiro do capim-elefante. Revista Ciência Agronômica, 37(1):91-96.

Martuscello, J. A., Fonseca, D. M. da., Nascimento Júnior, D. do., Santos, P. M., Ribeiro Junior, J. I., Cunha, D. N. F. V. da., \& Moreira, L. M. (2005). Características morfogênicas e estruturais do capim-xaraés submetido à adubação nitrogenada e desfolhação. Revista Brasileira de 
Zootecnia, 34(5):1475-1482. 10.1590/S151635982005000500007

Martuscello, J. A., Fonseca, D. M. da., Nascimento Júnior, D. do., Santos, P. M., Cunha, D. N. F. V. da., \& Moreira, L. M. (2006). Características morfogênicas e estruturais de capim-massai submetido a adubação nitrogenada e desfolhação. Revista Brasileira de Zootecnia, 35(3):665-671. $10.1590 /$ S1516-35982006000300006

Mesquita, E. E., \& Neres, M. A. (2008). Morfogênese e composição bromatológica de cultivares de Panicum maximum em função da adubação nitrogenada. Revista Brasileira de Saúde e Produção Animal, 9(2):201-209.

Mota, V. J. G., Reis, S. T., Sales, E. C. J., Rocha Júnior, V. R., Oliveira, F. G., Walker, S. F., Martins, C. E., \& Cóser, A. C. (2010). Lâminas de irrigação e níveis de nitrogênio em pastagem de capim-elefante no período seco do ano no norte de Minas Gerais. Revista Brasileira de Zootecnia, 39(6):1191-1199. 10.1590/S151635982010000600005

Nussio, L. G., Manzano, R. P., \& Pedreira, C. G. S. (1998). Valor alimentício em plantas do gênero Cynodon. In: Simpósio Sobre Manejo da Pastagem, 15, 1998, Piracicaba. Anais. Piracicaba: FEALQ/ESALQ: pp. 203-242.

Raij, B. van. (1991). Fertilidade do solo e adubação. Piracicaba: Associação Brasileira para Pesquisa da Potassa e do Fosfato. 343 p.

Rocha, G.P., Evangelista, A. R., Lima, J. A. de., \& Rosa, B. (2002). Adubação nitrogenada em gramíneas do Gênero Cynodon. Ciência Animal Brasileira, 3(1):1-9.

Rodrigues, B. H. N., Magalhães, J. A., \& Lopes, E. A. (2005). Irrigação e adubação nitrogenada em três gramíneas forrageiras no Meio-Norte do Brasil. Revista Ciência Agronômica, 36(3):274-278.

Ribeiro, A. C., Guimaraes, P. T. G., \& Alvarez, V. V. H. (Ed.) (1999). Recomendações para o uso de corretivos e fertilizantes em Minas Gerais - $5^{a}$ Aproximação. Viçosa, MG: Comissão de Fertilidade do Solo do Estado de Minas Gerais. 359 p.

SAS Institute. 2003. SAS System for Windows. Version 9.0. Cary: SAS Institute Inc. 2 CD-ROMs.

Van Soest, P. J. (1965). Voluntary intake in relation to chemical composition and digestibility. Journal of Animal Science, 24(3):834-843. 10.2527/ jas $1965.243834 \mathrm{x}$

Van Soest, P. J., \& Robertson, J. B. (1985). Analysis of forages and fibrous foods. Ithaca: Cornell University. 202 p.

Van Soest, P. J., Robertson, J. B., \& Lewi, B. A. (1991). Methods for dietary fiber, neutral detergent fiber, and nonstarch polysaccharides in relation to animal nutrition. Journal of Dairy Science, 74:3583-3597.

Vitor, C. M. T., Fonseca, D. M. da., Cóser, A. C., Martins, C. E., Nascimento Júnior, D. do., \& Ribeiro Júnior, J. I. (2009). Produção de matéria seca e valor nutritivo de pastagem de capim-elefante sob irrigação e adubação nitrogenada. Revista Brasileira de Zootecnia, 38(3):435-442. doi:10.1590/S1516-35982009000300006

Volenec, J. J., \& Nelson, C. J. (1984). Carbohydrate metabolism in leaf meristems of tall fescue. II. Relationship to leaf elongation rates modified by nitrogen fertilization. Plant Physiology. 74(3):595-600. doi:10.1104/pp.74.3.595 